\title{
The Response of The Friction High Strength Bolt Connection for Steel Truss Bridge
}

\author{
Anis Rosyidah $^{1}$, Okky Irawan $^{1}$, Praganif Sukarno ${ }^{1}$, I Ketut Sucita ${ }^{1}$ \\ \{anis.rosyidah@sipil.pnj.ac.id, okky.irawan@gmail.com, praganif.sukarno@sipil.pnj.ac.id, \\ i.ketutsucita@sipil.pnj.ac.id\}
}

Civil Engineering Department, Politeknik Negeri Jakarta, Depok, Jl. Prof. Dr. Siwabessy, Kampus UI Depok, Indonesia, $16425^{1}$

\begin{abstract}
High strength bolt joints used on the steel truss bridge are the mechanism of slip-critical. This mechanism relies on the clamping force of high strength bolt pretension led to friction between the surface of the tied steel plates, so the forces acting on the elements of the steel bridge held by the friction. In order to get the ratio of the pretensioning and observe the mode of failure, then the experiments in the laboratory and the simulation using software were carried out. The method used in this experiment was trial and error so that the value of the pretensioning of high strength bolts needed to reach the maximum axial load press was retrieved. There are four types of the surface coating of the tied steel; milling, grit-blast cleaning, coat of primer paint by grit-blast cleaning and coat of hot-dip galvanized given chromate treatment. The results obtained show that the ratio of the pretensioning on high strength bolt between the simulation and the experiments do not look different; the range is 0.97 . The pattern of failure that occurs in the simulation tends to be more regular and quite small in comparison with the experimental results.
\end{abstract}

Keywords: pretensioning, the pattern of failure, bolt connection, friction type, and clamping force.

\section{Introduction}

Nowadays, it commonly found the use of high-quality bolt joint as a means of connecting to steel structures, especially in steel bridges in Indonesia. The joint used on bridges are generally shear-type joint; those are connection details that cause the bolt to receive the shear force. The working mechanism of the high-quality bolt joint used on steel bridges is the slipcritical mechanism [1], [2], [3]. This mechanism relies on the clamping force of high-quality bolt pretensioning, which causes friction between the surface of the jointed steel plates so that forces on steel bridge elements will be held by the friction force [4], [5].

Much research has done on the surface of steel joints that will accept the friction force because of the use of a shear-type joint with a slip-critical mechanism [6]. Previous research on steel joint using high-quality bolts have been done. The results of the study stated that Finite Element Analysis (FEA) makes it easy to simulate the behavior of beam-column end-plate joints at a low and relatively fast cost [6], [1]. The numerical analysis of the end-plate connection also shows that the high-quality bolts given pretensioning on the connection model using software has provided excellent results based on theory and the conducted experiment [7].

\subsection{Steel Bridge Connection}


Joint commonly used for bridges are shear-type joints in which the detail of the connection causes the bolt to receive the shear force. This connection used because it is relatively easy to make and install the detail. Based on the tightening process, the shear-type connection has two different working mechanisms when high-quality bolts are used and tightened by pretensioning [8]. The two mechanisms are called the slip-critical mechanism and the bearing mechanism [9].

The bolt connection with the slip-critical or bearing mechanism cannot be distinguished from its physical appearance [10], [4]. This type of connection can only be distinguished when the bolt connection is given loading. The slip-critical mechanism will work if the bolt does not slip (remains at its place) at the planned load. Its strength depends on the amount of friction resistance that occurs. Conversely, the overload mechanism will work if the bolt slips (shifts or moves due to a gap caused by a hole larger than the diameter of the bolt) when the connection is loaded [1].

The high-quality connection bolts of shear-type with slip-critical mechanisms are more widely used in structures that are dominated by dynamic loads or alternating loads such as bridges, which can cause fatigue failure in the joint structure. Although the strength is smaller than the connection of the support mechanism, this type of connection is used because it is more effective in reducing the risk of fatigue failure [11].

\section{Research Methods}

This research was carried out using the help of finite element software by making 18 test simulation models. There were four types of preparation that consisted of factory-scale steel surfaces; steel surfaces through the grit-blast cleaning process, steel surfaces with primer paint layers that passed the grit- blast cleaning and steel surface with hot-dip galvanized coating given chromate treatment. Each model is made according to its original shape by using maximum compressive force according to empirical testing, and pretensioning on the model was sought by a trial and error strategy [12], [13]. The making of the specimen model used finite software elements (Fig. 1).

The software analysis consists of three stages[14]. The preprocessing phase involved creating or inputting data that contained the data needed to carry out the analysis. The model making was done by entering geometry in the facility provided consisted of three phases, namely preprocessing, processing, and postprocessing [15], at software finite element. The model simulation made like an experimental test, which done gradually. This module functioned to determine the sequence of steps based on the loads given. The mesh module functioned to divide the part geometry made into several elements and nodal. The type of mesh used was hexagonal with mesh instance. Each part used the same mesh type and size [16]. 


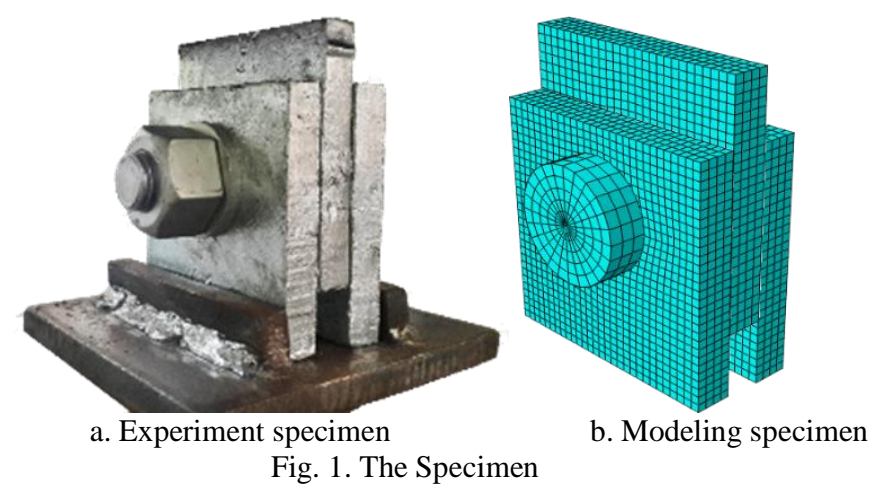

In the processing phase, the analysis of the preprocessing phases that have been previously defined was carried out. This phase was a numerical settlement process. The postprocessing phase showed the results of the processing phase. The results displayed in the software were stress values, and displacements occurred. The results are presented interactively by using the available visualization modules, namely in the form of images, animations, and graph plots [6], [17].

\section{Result And Discussion}

\subsection{Connection Test Result}

The response of this connection type in stress is shown in Fig. 2. It shows the contour of the von-mises plate and the high-quality bolt as resulted by pretensioning on the computerized model.

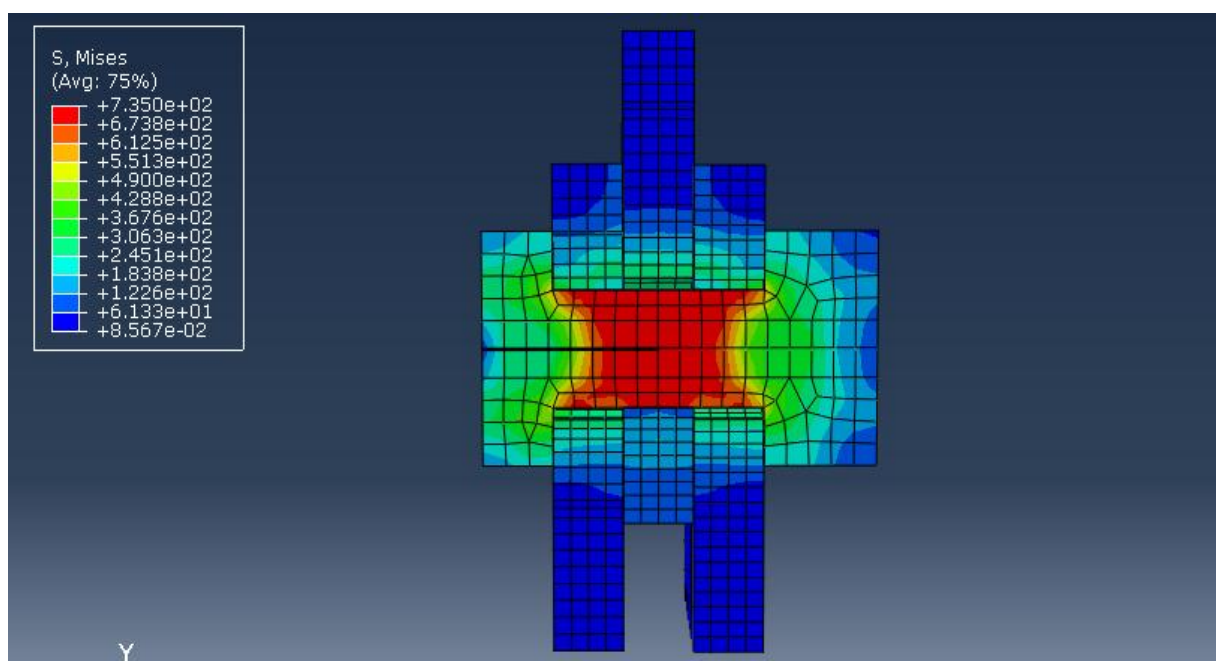

Fig. 2. Distribution of $\sigma_{\text {von-mises }}$ resulted by Pretensioning at The Half Model (M1) 
Table 1. Comparison of Pretensioning Result

\begin{tabular}{|c|c|c|c|c|c|}
\hline \multirow{2}{*}{\multicolumn{2}{|c|}{$\begin{array}{c}\text { Specimen } \\
\text { (surface } \\
\text { condition) }\end{array}$}} & \multirow{2}{*}{$\begin{array}{r}\text { Max. } \\
\text { load } \\
(k N) \\
\end{array}$} & \multirow{2}{*}{$\begin{array}{r}\text { Friction } \\
\text { coefficient }\end{array}$} & \multicolumn{2}{|c|}{ Pretensioning } \\
\hline & & & & Experiment & Simulation \\
\hline \multirow{5}{*}{$\stackrel{\substack{\Xi \\
\Xi}}{\Xi}$} & M1 & 156.90 & 0.248 & 316.00 & 308.9 \\
\hline & M2 & 184.00 & 0.291 & 316.00 & 307.1 \\
\hline & M3 & 153.50 & 0.243 & 316.00 & 306.4 \\
\hline & M4 & 131.20 & 0.208 & 316.00 & 310.7 \\
\hline & M5 & 147.40 & 0.233 & 316.00 & 307.7 \\
\hline \multirow{5}{*}{ 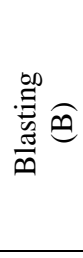 } & B1 & 308.00 & 0.487 & 316.00 & 306.3 \\
\hline & B2 & 258.60 & 0.409 & 316.00 & 308.3 \\
\hline & B3 & 287.80 & 0.455 & 316.00 & 305.6 \\
\hline & B4 & 255.90 & 0.405 & 316.00 & 307.7 \\
\hline & B5 & 219.30 & 0.347 & 316.00 & 307.8 \\
\hline \multirow{4}{*}{ 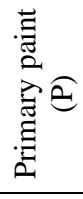 } & $\mathrm{P} 1$ & 208.00 & 0.329 & 316.00 & 309.9 \\
\hline & $\mathrm{P} 2$ & 138.70 & 0.219 & 316.00 & 312.2 \\
\hline & P3 & 167.70 & 0.265 & 316.00 & 307.2 \\
\hline & P5 & 157.60 & 0.249 & 316.00 & 308.0 \\
\hline \multirow{4}{*}{ 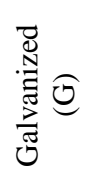 } & G1 & 190.00 & 0.301 & 316.00 & 306.7 \\
\hline & G3 & 239.00 & 0.378 & 316.00 & 308.3 \\
\hline & G4 & 160.00 & 0.253 & 316.00 & 307.1 \\
\hline & G5 & 226.00 & 0.358 & 316.00 & 307.2 \\
\hline
\end{tabular}

As displayed in Table 1, it can be seen that the amount of pretensioning in the computerized model has a smaller value and a slight difference than the experimental test. It shows that the alternative method for pretensioning on the experimental test conducted does not have many variables that influence it. So, the results of this study on high-quality bolt pretensioning can be considered as good.

\subsection{Failure Connection Pattern}

The shear connection using a slip-critical mechanism is considered to collapse when the slip occurs. Failure at this connection is due to compressive axial load that exceeds the friction strength of the joint surface. In this study, slips that occur only on the vertical axis / y axis/translation y. Identification is made by comparing the results of the decline in the simulation model and the experimental model. The pattern of stress distribution that occurs in experimental and simulation models due to the pretensioning of high-quality bolts and compressive axial forces that cause friction on the connection surface can be seen in Fig. 3 to Fig. 6. 


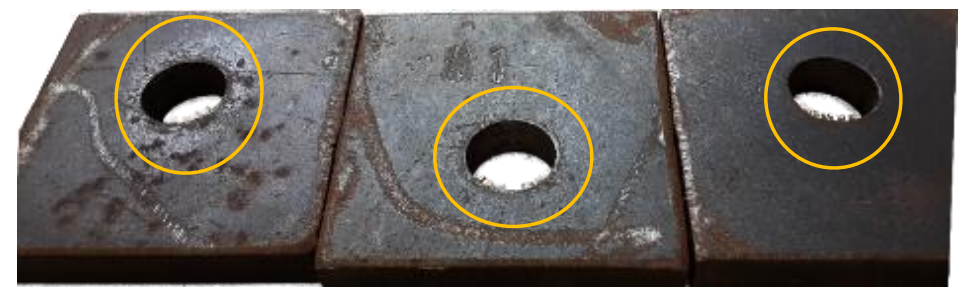

a). Experiment

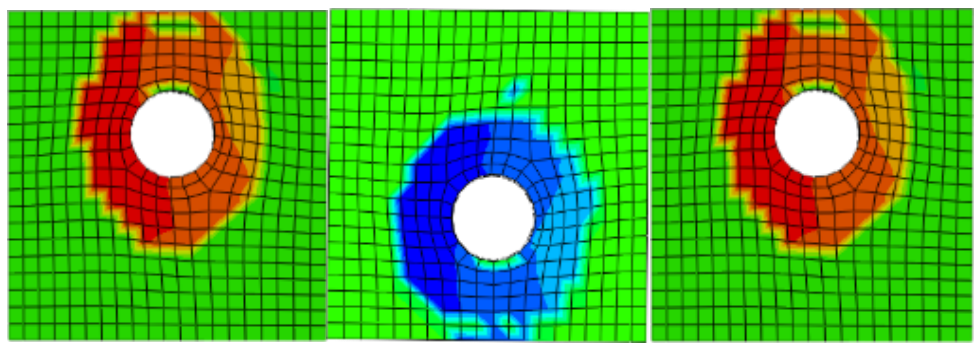

b). Simulation

Fig. 3. Stress Distribution Pattern on Milling Surface Type (M) after being tested

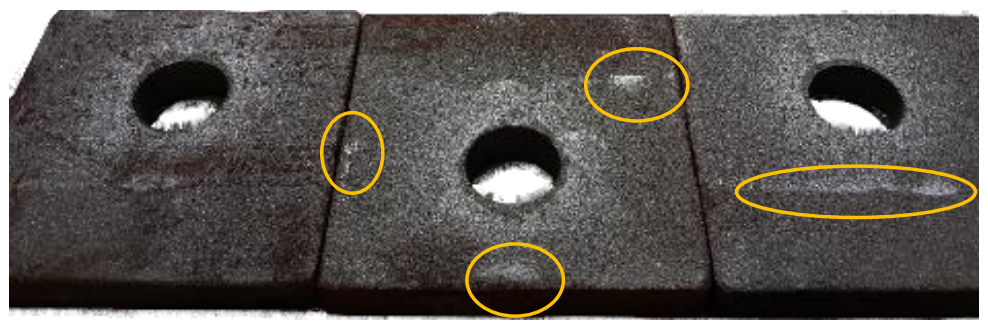

a). Experiment

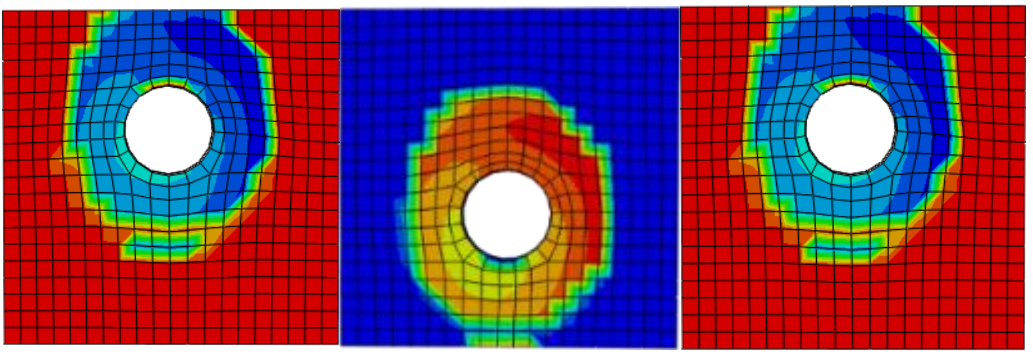

b). Simulation

Fig. 4. Stress Distribution Pattern on Surface of Blasting Type (B) after being tested 


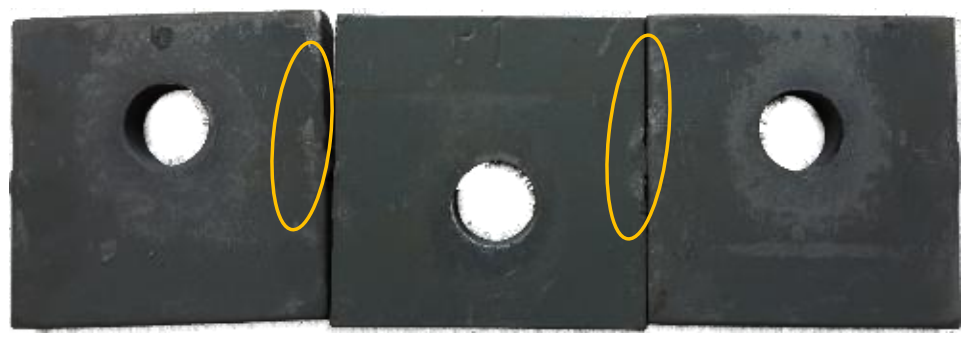

a). Experiment

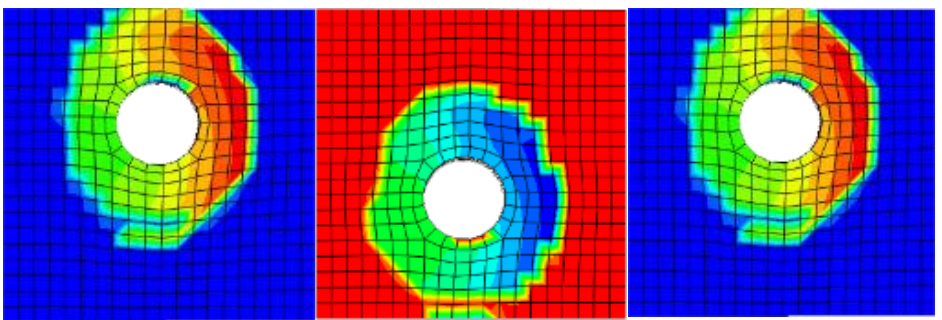

b). Simulation

Fig. 5. Distribution of Stress Patterns on Primary Surface Types (P) after being tested

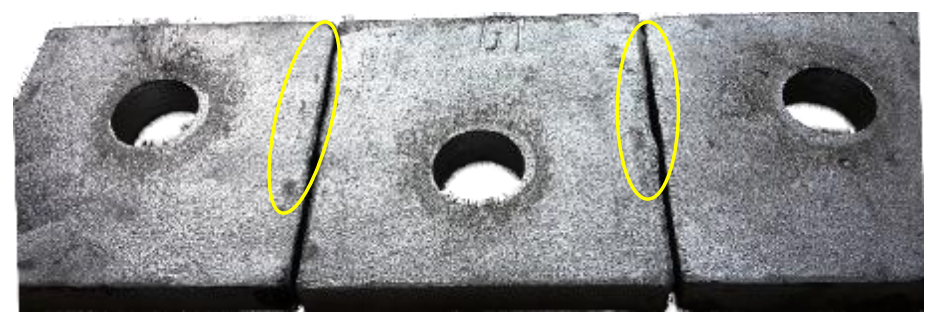

a). Experiment
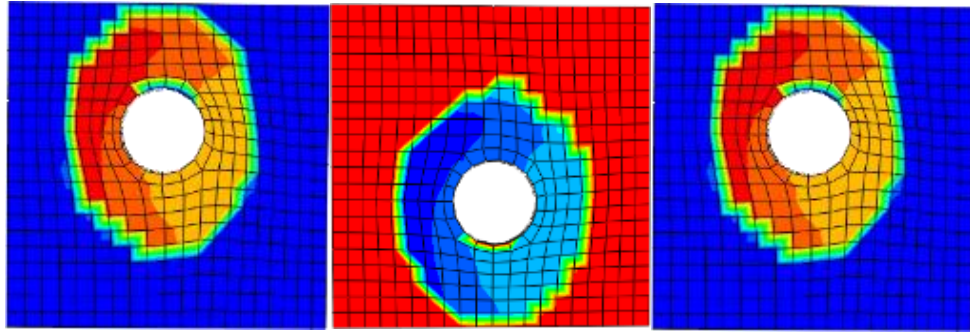

b). Simulation

Fig. 6. Distribution of Stress Patterns on Galvanized

(G) after being tested

From the identification (Fig. 3 - 6), it can be seen that the comparison between the experimental model and the simulation model has a considerable difference. The pattern of spreading stress that occurs in the experimental and simulation models due to pretensioning of 
the high-quality bolt and compressive axial forces that cause friction forces on the junction surface. This result similar with reaserch Hwang (2013) [15] dan Zhao (2018) [6].

\section{Conclusion}

From the results of research conducted by the response of the friction high strength bolt connection, it can be concluded that pretensioning on the type of factory-scale steel surface layer has an average value of $308.2 \mathrm{kN}$. The type of steel surface through the grit-blasting cleaning process has an average value of $307.1 \mathrm{kN}$. The type of surface layer with primary paint that through the grit-blast cleaning process, it has an average value of $309.3 \mathrm{kN}$. So the type of hotdip galvanized surface layer given chromate treatment has an average value of $307.3 \mathrm{kN}$.

The value comparison of pretensioning on high-quality bolts between experimental testing and simulation models shows good results. It can be seen from the ratio between the results of experimental testing and simulation models; the factory-scale steel surface layer is 0.9752 . The steel surface layer through the process of cleaning grit-blast is 0.9720 . The primary paint layer through the process of cleaning grit-blast is 0.9789 . The hot-dip galvanized layer by given the chromate treatment is 0.9725 . Pretensioning simulation results by using the computerized model show smaller results than the experiment.

The failure pattern that occurs in the computerized model tends to be more orderly and quite small when compared with the results of experimental testing. The distribution of stresses in the experimental model and simulation model shows a similar pattern.

\section{Acknowledgment}

Special acknowledgment to the Center for Research and Community Devotion, and PT Bukaka, which have already provided financial and material support to carry out this research.

\section{References}

[1] Y. Shi, M. Wang, and Y. Wang, "Analysis on Shear Behavior of High-Strength Bolts Connection,” Int. J. Steel Struct., vol. 11, no. 2, pp. 203-204, 2011.

[2] G. L. Kulak, J. W. Fisher, and J. H. A. Struik, Guide to Design Criteria for Bolted and Riveted Joints Second Edition. American Institute of Steel Construction, Inc., Inc., 2001.

[3] Geoffrey Kulak, High Strength Bolts, A Primer for Structure Engineers. United States of America, 2002.

[4] W. Dewobroto and H. Wijaya, "Pengaruh Pemakaian Baut Mutu Tinggi dan Baut Biasa terhadap Kinerja Sistem Sambungan dengan Ring-Khusus-Beralur," J. Tek. Sipil, vol. 19, no. Agustus, pp. 123-132, 2012.

[5] J. Yang and J. T. DeWolf, "Relaxation in High-Strength Bolted Connections Using Galvanized Steel,” J. Bridg. Eng., vol. 5, no. May, pp. 99-106, 2000.

[6] Z. Zhao, B. Liang, H. Liu, and Y. Li, "Simplified Numerical Model for High-Strength Bolted Connections," Eng. Struct., vol. 164, no. February, pp. 119-127, 2018.

[7] F. Liu, X. Lu, L. Zhao, J. Zhang, N. Hu, and J. Xu, "An interpretation of the load distributions in highly torqued single-lap composite bolted joints with bolt-hole clearances," Compos. Part B, 2017.

[8] A. Committee, Specification for Structural Steel Buildings. American Institute of Steel Construction All, 2016. 
[9] C. RCSC, Specification for Structural Joints Using High-Strength Bolts, vol. 2014, no. April. 2015.

[10] W. Dewobroto, L. Hidayat, J. Widjajakusuma, and Kelvin, "Studi Karakteristik Baut Mutu Tinggi ( A325 dan Grade 8.8 ) Terhadap Tarik dan Pengaruhnya pada Perencanaan Sambungan Studi Karakteristik Baut Mutu Tinggi ( A325 dan Grade 8 . 8 ) Terhadap Tarik dan Pengaruhnya pada Perencanaan Sambungan," in Seminar HAKI, 2016, no. August.

[11] W. Huili and T. Yanbing, "Study on Fatigue Reliability of High-Strength Bolt Joint in Corrosion Environment," in International Conference on Chemical, Material and Food Engineering (CMFE-2015), 2015, no. 1, pp. 187-190.

[12] Y. Peng, G. Li, H. Lian, and S. Xia, "The properties of High Strength Bolt Connection Pairs with Hot-dip Coating," Adv. Mater. Res., vol. 597, pp. 1042-1045, 2012.

[13] H. Nah, H. Lee, and K. Kim, "Evaluation of Long-term Relaxation for High-strength Bolted Connections," in Proceedings of ICAPP '10 San Diego, CA, USA, 2010, no. June, pp. 1965-1970.

[14] K. Bommisetty and K. Narayanan, "Three-Dimensional Finite Element Analysis of Bolted Joint With Helical Thread Connection," in Proceedings of the ASME 2014 Gas Turbine India Conference, 2016, pp. 1-8.

[15] H. Hwang, "Bolted joint torque setting using numerical simulation and experiments †,” J. Mech. Sci. Technol., vol. 27, no. 5, pp. 1361-1371, 2013.

[16] C. T. Mccarthy and M. A. Mccarthy, "Three-dimensional finite element analysis of single-bolt, single-lap composite bolted joints : Part II — effects of bolt-hole clearance," J. Compos. Struct., vol. 71, pp. 159-175, 2005.

[17] M. A. Mccarthy, C. T. Mccarthy, V. P. Lawlor, and W. F. Stanley, "Threedimensional finite element analysis of single-bolt, single-lap composite bolted joints : part I - model development and validation," J. Compos. Struct., vol. 71, pp. 140158, 2005. 